\title{
Onion (Allium cepa L.) peel extract has anti-platelet effects in rat platelets
}

\author{
Ju-Ye Ro ${ }^{1+}$, Jin-Hyeob Ryu ${ }^{1,3+}$, Hwa-Jin Park ${ }^{2}$ and Hyun-Jeong Cho ${ }^{1 *}$
}

\begin{abstract}
The effects of onion peel extract (OPE) in collagen $(5 \mu \mathrm{g} / \mathrm{mL})$-stimulated washed rat platelet aggregation were investigated. OPE inhibited platelet aggregation via inhibition of aggregation-inducing molecules, intracellular $\mathrm{Ca}^{2+}$ and thromboxane $\mathrm{A}_{2}\left(\mathrm{TXA}_{2}\right)$ by blocking cyclooxygenase-1 (COX-1) and TXA $\mathrm{A}_{2}$ synthase (TXAS) activities in a dose-dependent manner. In addition, OPE elevated the formation of cyclic adenosine monophosphate (CAMP), aggregation-inhibiting molecule, but not cyclic guanosine monophosphate (cGMP). High performance liquid chromatography (HPLC) analysis of OPE revealed that OPE contains quercetin, one of the major flavonoids, which has anti-platelet effect. In conclusion, we suggest that OPE is an effective inhibitor of collagen-stimulated platelet aggregation in vitro. Therefore, it can be a promising and safe strategy for anti-cardiovascular diseases.
\end{abstract}

Keywords: Onion peel extract; Quercetin; Platelet aggregation; Intracellular $\mathrm{Ca}^{2+}$; Cyclic adenosine monophosphate; Thromboxane $\mathrm{A}_{2}$

\section{Introduction}

When normal blood vessels are damaged, platelets are activated by stimuli which are present in the walls of blood vessels, and induce aggregation (Nieswandt and Watson 2003). Platelets are activated by agonists such as collagen, thrombin and ADP, and it induces the signals by activating multiple $G$ protein-mediated pathways to activate platelet-shape change, degranulation and aggregation (Nieswandt and Watson 2003; Offermanns 2006). But in many cardiovascular diseases such as acute coronary syndromes, atherosclerosis, stroke and peripheral vascular diseases, excessive platelet activation is regarded as the cause of thrombosis (FitzGerald et al. 1987; Davi and Patrono 2007; Kapoor 2008). Abnormal platelet aggregation leads to excessive $\mathrm{TXA}_{2}$ formation interacts with other platelets, inducing thrombotic disorders (Miller et al. 1977; FitzGerald et al. 1987). Therefore, the development of an anti-platelet agent could be a fundamental therapeutic approach to cardiovascular diseases (Bhatt and Topol 2003; Jackson and Schoenwaelder 2003). The activation of phospholipase C (PLC) through G protein, which results in the formation of inositol 1,4,5-triphosphate $\left(\mathrm{IP}_{3}\right)$ and

\footnotetext{
* Correspondence: hjcho@konyang.ac.kr

${ }^{\dagger}$ Equal contributors

${ }^{1}$ Department of Biomedical Laboratory Science, College of Medical Science, Konyang University, 685, Gasuwon-dong, Seo-gu, Daejeon 302-718, Korea Full list of author information is available at the end of the article
}

diacylglycerol (DG) plays an important role in platelet aggregation, contributing to elevated cytosolic free $\mathrm{Ca}^{2+}$ $\left(\left[\mathrm{Ca}^{2+}\right]_{\mathrm{i}}\right)$ (Brass and Joseph 1985; Williamson et al. 1985). DG is hydrolyzed by DG lipase to produce arachidonic acid (20:4). The metabolic pathways of 20:4 lead to TXA 2 formation which is one of the positive-feedback mediators during platelet aggregation through COX-1 and TXAS pathways (Baumgartner and Haudenschild 1972; Hamberg et al. 1975). On the other hand, cAMP and cGMP are known as anti-platelet aggregatory regulators. The major inhibitors of platelet activation are nitric oxide (NO) and prostacyclin $\left(\mathrm{PGI}_{2}\right)$, which raise the levels of cAMP and cGMP (Trovati et al. 1997). The aggregatory effects of cAMP and cGMP on platelets are mediated via cAMP and cGMP-dependent protein kinases, which phosphorylate substrate protein, vasodilator-stimulated phosphoprotein (VASP) entailed in the inhibitory effect of platelet aggregation (Halbrugge et al. 1990). Thus, cAMP and cGMP are anti-platelet second messengers in platelet aggregation, and a substance which elevates the levels of cAMP and cGMP may control platelet aggregation.

Onion (Allium cepa L.) has been reported to have beneficial effects, including preventing stroke, coronary thrombosis, atherosclerosis, hyperlipidemia and hypertension (Bordia et al. 1975; Kawamoto et al. 2004). Especially, it has been reported to inhibit platelet aggregation induced 
by various agonists in vitro and in vivo (Moon et al. 2000; Bordia et al. 1996). In dogs, onion juice reduced collageninduced whole-blood platelet aggregation (Briggs et al. 2001). Also, in rats treated with aqueous extracts of garlic and onion ( $500 \mathrm{mg} / \mathrm{kg}$ of body weight) for 4 weeks, $\mathrm{TXB}_{2}$ levels were significantly inhibited compared with that of control in serum (Bordia et al. 1996). These results may be linked by quercetin known as one of the most abundant flavonoids in vegetables (Crozier et al. 1997; Ewald et al. 1999). Epidemiological data suggest that those who consume a diet rich in quercetin-containing foods may have a reduced risk of cardiovascular diseases (Glässer et al. 2002; Kris-Etherton et al. 2004). Indeed, collagen-stimulated platelet aggregation was inhibited after ingestion of onion soup high in quercetin in a time-dependent manner (Hubbard et al. 2006). Therefore, in vitro and in vivo, onion has been concerned with anti-thrombotic effects by inhibiting platelet aggregation and activation (Kawakishi and Morimitsu 1988; Ali et al. 1999; Moon et al. 2000; Briggs et al. 2001). However, while those studies have investigated the effects of anti-platelet aggregation of onion bulb extract, the signaling for anti-platelet effects of the outer skin extract of onion have been barely analyzed. Therefore, this work was carried out in an effort to investigate the anti-platelet effects of outer skin of onion. In the present study, we investigated that OPE has inhibitory effects on platelet-mediated thrombotic disorders via down-regulation of $\mathrm{TXA}_{2}$ through reducing the $\left[\mathrm{Ca}^{2+}\right]_{\mathrm{i}}, \mathrm{COX}-1$ and TXAS activities, as well as also up-regulation of cAMP levels in collagen-stimulated rat platelet aggregation without any toxicity in vitro.

\section{Results and Discussion}

\section{OPE possesses quercetin in highest level}

We analyzed quercetin of OPE with HPLC. In the previous study, quercetin has been reported to inhibit collageninduced platelet aggregation (Hubbard et al. 2006). Also, it is known that outer skin of onion contains much higher levels of quercetin than its bulb (Hertog et al. 1992; Prakash et al. 2007). Therefore, it was used as a standard in this study. In Figure 1, HPLC analysis revealed that the retention time of quercetin was $26.6 \mathrm{~min}$ (Figure 1A) and OPE has three peaks mainly, the highest one proved quercetin (26.6 min) (Figure 1B). Calibration curve were linear over the range of 20 to $500 \mu \mathrm{g} / \mathrm{mL}$ of quercetin, and it was calculated from calibration curve. The content of quercetin from OPE was $167.3 \pm 0.48 \mathrm{mg} / \mathrm{g}(16.7 \pm 0.1 \%$ of quercetin in OPE) (data not shown). In addition, we examined platelet aggregation reactions in the presence of quercetin. The half-maximal inhibitory concentration $\left(\mathrm{IC}_{50}\right)$ of quercetin in collagen $(5 \mu \mathrm{g} / \mathrm{mL})$-induced platelet aggregation was $6 \mu \mathrm{g} / \mathrm{mL}(32.0 \pm 4.0 \%, \mathrm{n}=3$, data not shown). These results show that anti-platelet effects of OPE is linked with quercetin as a main component, although other two peaks were not unconfirmed (Figure 1).

\section{A}

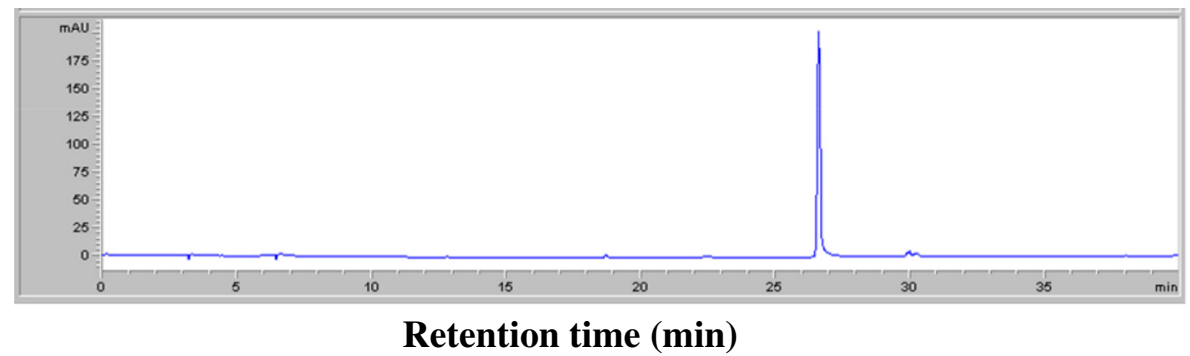

B

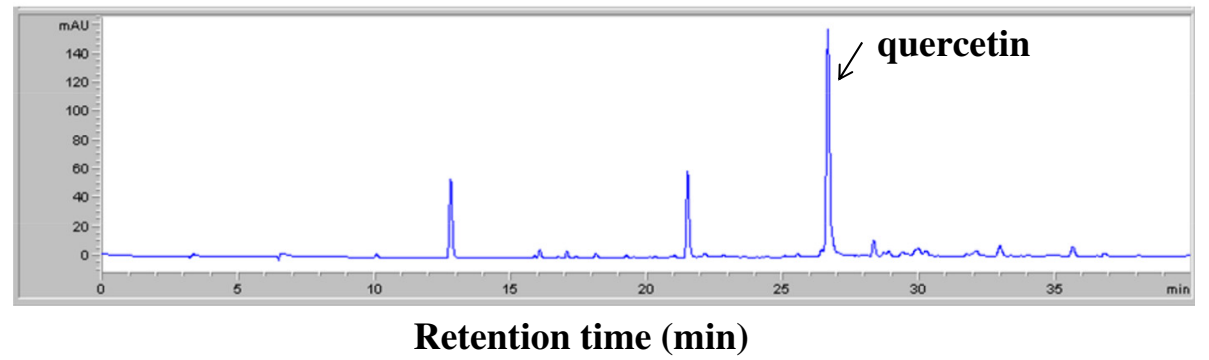

Figure 1 HPLC chromatograms of OPE and internal standard (quercetin). (A) The standard chromatogram of quercetin. (B) The chromatogram of OPE $(0.5 \mathrm{mg} / \mathrm{mL})$. 
OPE inhibits platelet aggregation via down-regulation of $\left[\mathrm{Ca}^{2+}\right]_{\mathrm{i}}$ levels

Anti-platelet aggregation effect of OPE was determined. Washed platelets $\left(10^{8}\right.$ cells $\left./ \mathrm{mL}\right)$ were activated with collagen $(5 \mu \mathrm{g} / \mathrm{mL})$ in the presence of $2 \mathrm{mM} \mathrm{CaCl}_{2}$ with or without various concentrations of OPE. Platelet aggregation rate induced by collagen only was $74.9 \pm 2.7 \%$, but OPE (50, 100 and $500 \mu \mathrm{g} / \mathrm{mL})$ significantly inhibited platelet aggregation in a dose-dependent manner (56.4 \pm 6.7, $25.3 \pm 7.3$ and $2.0 \pm 1.2 \%$, respectively) (Figure 2A). The inhibition rate was increased significantly by OPE (25.3\%, 66.7\% and 97.3\%, respectively). These results suggest that OPE has anti-platelet effects in a dosedependent manner. $\mathrm{IC}_{50}$ value of $\mathrm{OPE}$ was $80.0 \mu \mathrm{g} / \mathrm{mL}$.

Intracellular calcium ions level $\left(\left[\mathrm{Ca}^{2+}\right]_{\mathrm{i}}\right)$ play a key role in regulation of platelet function on their migration and adhesion (Detwiler et al. 1978). An elevation of $\left[\mathrm{Ca}^{2+}\right]_{i}$ activates platelet aggregation (Nishikawa et al. 1980). In the previous study, quercetin has been reported to inhibit collagen-induced platelet aggregation through inhibition of $\left[\mathrm{Ca}^{2+}\right]_{\mathrm{i}}$ and glycoprotein VI signaling pathway (Hubbard et al. 2003). Therefore, we investigated if OPE inhibits $\left[\mathrm{Ca}^{2+}\right]_{\mathrm{i}}$ under collagen exposure. When Fura 2-loaded platelets $\left(10^{8}\right.$ cells $\left./ \mathrm{mL}\right)$ were stimulated by collagen $(10 \mu \mathrm{g} / \mathrm{mL})$, the level of $\left[\mathrm{Ca}^{2+}\right]_{\mathrm{i}}$ increased from $98.2 \pm$ 10.3 to $704.3 \pm 76.7 \mathrm{nM}$ (Figure $2 \mathrm{~B}$ ). However, this was significantly reduced by various concentrations (50, 100 and $500 \mu \mathrm{g} / \mathrm{mL})$ of OPE $(450.1 \pm 85.4,143.1 \pm 7.0$ and $103.6 \pm$ $2.9 \mathrm{nM}$, respectively) in a dose-dependent manner. These results suggest that inhibitory effects of OPE on collagenstimulated platelet aggregation was due to lowering of the level of $\left[\mathrm{Ca}^{2+}\right]_{\mathrm{i}}$, one of the key factor for platelet activation.

\section{OPE decreases the production of TXA 2}

$\mathrm{TXA}_{2}$ is a powerful stimulator and potent vasoconstrictor that is produced by platelets during their aggregation (Bunting et al. 1983; Cho et al. 2006). Collagen-stimulated aggregation of platelets induces $\alpha \mathrm{IIb} \beta 3$-mediated outsidein signaling and aggregation through the production of
$\mathrm{TXA}_{2}$ (Cho et al. 2003). Also, aggregating platelets interact with coronary artery and $\mathrm{TXA}_{2}$ contribute to the direct activation of coronary smooth muscle by platelet aggregation (Houston et al. 1986). Therefore, $\mathrm{TXA}_{2}$ is considered as the important factor in thrombotic and cardiovascular diseases (Müller 1990). Therefore, we determined whether OPE reduce the production of $\mathrm{TXA}_{2}$ under collagen exposure. $\mathrm{TXB}_{2}$ (a stable metabolite of $\mathrm{TXA}_{2}$ ) levels in intact platelets was $1.2 \pm 0.4 \mathrm{ng} / 10^{8}$ cells, and this was markedly increased to $46.4 \pm 7.8 \mathrm{ng} / 10^{8}$ cells in the collagenstimulated platelets (Figure $3 \mathrm{~A}$ ). However, various concentrations of OPE $(50,100$ and $500 \mu \mathrm{g} / \mathrm{mL})$ significantly reduced the production of $\mathrm{TXB}_{2}$ in a dose-dependent manner $\left(20.4 \pm 7.8,17.3 \pm 1.8\right.$ and $15.8 \pm 5.5 \mathrm{ng} / 10^{8}$ cells, respectively). OPE strongly inhibited $\mathrm{TXB}_{2}$ level (inhibition rate: $65.9 \%$ at $500 \mu \mathrm{g} / \mathrm{mL}$ ). In addition, quercetin $\left(6 \mu \mathrm{g} / \mathrm{mL}\right.$ ) was inhibited $\mathrm{TXB}_{2}$ level from $37.2 \pm 1.2$ (control) to $25.2 \pm 3.8 \mathrm{ng} / 10^{8}$ cells $(32.3 \%$ of inhibition, $\mathrm{n}=3$, data not shown). These results show that the inhibitory effects of $\mathrm{OPE}$ on $\mathrm{TXB}_{2}$ production were linked with quercetin. OPE may be regulate platelet aggregation via down-regulation of $\mathrm{TXA}_{2}$ production which is one of the powerful stimulators of platelets activation. Based on these findings, we suggest that the consumption of OPE may prevent platelet-mediated cardiovascular disorders.

We next investigated whether $\mathrm{TXB}_{2}$ down-regulation by OPE is directly related to inhibition of its metabolic enzyme, COX-1 or TXAS activity.

\section{OPE inhibits TXAS and COX-1 activity}

When platelets were stimulated by collagen, arachidonic acid (AA) converts to $\mathrm{TXA}_{2}$ via COX-1 and TXAS activities (Hamberg et al. 1975). We determined whether OPE had the effect on TXAS or COX-1 activity. First, TXAS activity assay was assessed by measuring $\mathrm{TXB}_{2}$ formation. In Figure 3B, OPE $(50,100$ and $500 \mu \mathrm{g} / \mathrm{mL})$ significantly inhibited TXAS from $122.3 \pm 1.5$ (control) to $87.1 \pm 7.2$ (29\% inhibition at $50 \mu \mathrm{g} / \mathrm{mL})$ and $76.1 \pm 12.6$ (38\% inhibition at $100 \mu \mathrm{g} / \mathrm{mL}) \mathrm{ng} / \mathrm{min} / \mathrm{mg}$-protein, respectively. 11
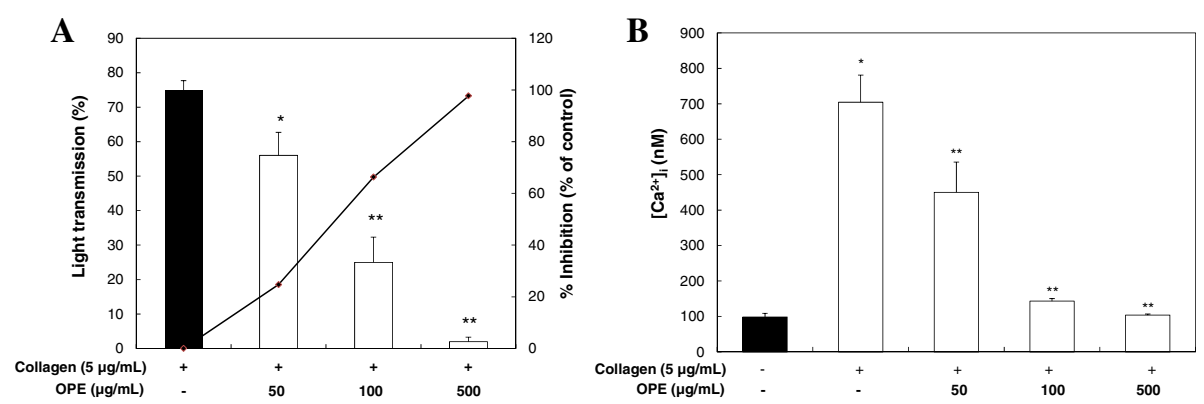

Figure 2 Effects of OPE on collagen-induced platelet aggregation and $\left[\mathrm{Ca}^{2+}\right]_{\mathrm{i}}$ mobilization. (A) Effects of OPE on collagen-induced platelet aggregation. Data are expressed as mean \pm SD $(n=7) .{ }^{*} p<0.05$ compared with that of collagen only. ${ }^{*} p<0.001$ compared with that of collageninduced platelet aggregation. (B) Effects of OPE on $\left[\mathrm{Ca}^{2+}\right]_{i}$ mobilization. Data are expressed as mean $\pm \mathrm{SD}(n=3) .{ }^{*} p<0.05$ compared with basal level. ${ }^{*} P<0.05$ compared with that of collagen-induced $\left[\mathrm{Ca}^{2+}\right]_{\mathrm{i}}$. 

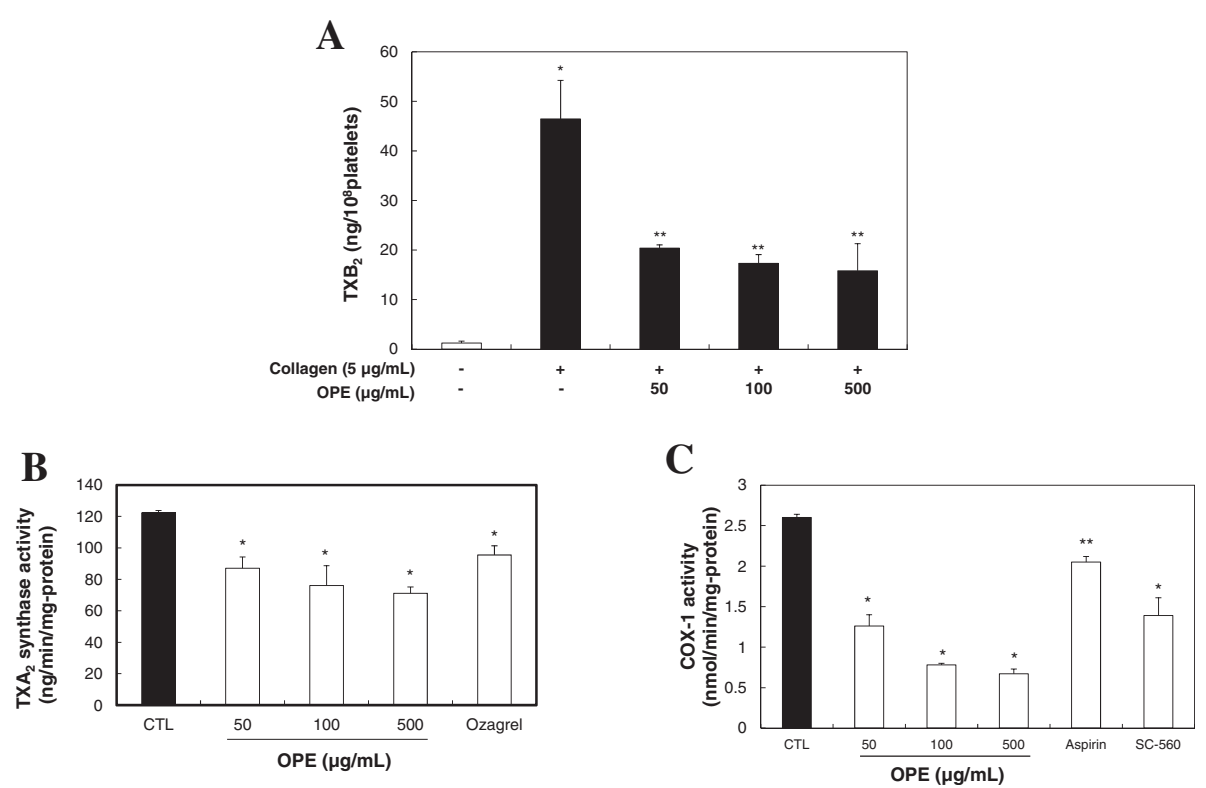

Figure 3 Effects of OPE on TXA $\mathbf{A}_{\mathbf{2}}$ formation. (A) TXA 2 production by OPE. Data are expressed as mean $\pm \mathrm{SD}(\mathrm{n}=3)$. ${ }^{*} p<0.05$ compared with basal level. ${ }^{* *} p<0.001$ compared with that of collagen-induced platelets. (B) Effects of OPE on TXA 2 synthase (TXAS) activity. Data represent mean $\pm S D(n=3) .{ }^{*} p<0.05$ compared with that of control. (C) Effects of OPE on COX-1 activity. Data represent mean $\pm S D(n=3) .{ }^{*} p<0.001$ and ${ }^{* *} p<0.05$ compared with that of control.

nM of ozagrel, a TXAS inhibitor, was used as a positive control and it decreased TXA 2 level to $95.5 \pm 5.9 \mathrm{ng} / \mathrm{min} /$ mg-protein (22\% inhibition). These results indicate that OPE inhibited TXAS, one of the TXA Th $_{2}$ metabolic enzymes, in a dose dependent manner.

We next assessed whether OPE affected COX-1 activity. After the addition of AA for $1 \mathrm{~min}$ at $37^{\circ} \mathrm{C}$, COX-1 activity was determined by measuring fluorescent compound resorufin which the reaction between $\mathrm{PGG}_{2}$ and ADHP produced. In Figure 3C, OPE (50, 100 and $500 \mu \mathrm{g} /$ $\mathrm{mL}$ ) significantly inhibited COX-1 activity from $2.6 \pm$ 0.1 (control) to $1.3 \pm 0.2(50 \%$ inhibition at $50 \mu \mathrm{g} / \mathrm{mL})$ and $0.8 \pm 0.1(69 \%$ inhibition at $100 \mu \mathrm{g} / \mathrm{mL}) \mathrm{nmoL} / \mathrm{min} /$ mg-protein, respectively. $500 \mu \mathrm{M}$ of aspirin and $330 \mathrm{nM}$ of SC-560, COX-1 inhibitors, were used as positive controls. They inhibited COX-1 activities $2.1 \pm 0.1$ (19\% inhibition) and $1.4 \pm 0.3 \mathrm{nmoL} / \mathrm{min} / \mathrm{mg}$-protein $(46 \%$ inhibition), respectively.

The inhibition of TXAS or COX-1 activity decreases $\mathrm{TXA}_{2}$ production and leads to anti-aggregatory effects (Gresele et al. 1991; FitzGerald et al. 1987). Therefore, the inhibitors of $\mathrm{TXA}_{2}$ production inducer (such as COX-1 and TXAS) can have the beneficial anti-thrombotic potential (Vilahur et al. 2007). In Figure 3, OPE reduced $\mathrm{TXB}_{2}$ production via regulation of COX-1 and TXAS activities. Therefore, our results suggest that OPE may have the beneficial property as an anti-platelet agent for cardiovascular diseases.

\section{OPE increases the formation of CAMP}

The elevation of the platelet aggregation induced by platelet stimulators is known to be lowered by either the production of cAMP or cGMP (Jang et al. 2002). We investigated whether OPE up-regulated the cellular level of cAMP or cGMP. In Figure 4A, collagen decreased intracellular cAMP level from $36 \pm 5.1 \mathrm{pmoL} / 10^{8}$ cells (basal level) to $28.3 \pm 6.0 \mathrm{pmoL} / 10^{8}$ platelets (control). However, when the platelets were incubated in the presence of both OPE and collagen $(5 \mu \mathrm{g} / \mathrm{mL})$, OPE (50, 100 and $500 \mu \mathrm{g} / \mathrm{mL}$ ) significantly increased the cAMP level in a dose-dependent manner $(51.8 \pm 4.8,54.7 \pm 4.8$ and $71.1 \pm 4.1 \mathrm{pmoL} / 10^{8}$ platelets, respectively). On the other hand, OPE did not elevate the cGMP level (Figure 4B). These results indicate that OPE regulates the production of cAMP in collagen-stimulated platelets.

In platelets, it is known that cAMP- and cGMPdependent effects inhibit agonist-induced increases in cytosolic calcium concentration and granule secretion (Aszodi et al. 1999). Considering these results, the inhibitory effect of OPE on $\left[\mathrm{Ca}^{2+}\right]_{\mathrm{i}}$ mobilization (Figure $2 \mathrm{~B}$ ) may be associated with up-regulation of cAMP levels by OPE (Figure 4A). Because the increased cAMP and cGMP levels affect activating PKA and PKG respectively, these enzymes phosphorylate their substrate proteins resulting in negative regulation of platelet aggregation ( $\mathrm{Li}$ et al. 2003). Therefore, increased cAMP levels by OPE on collagen-induced platelet aggregation might be associate 

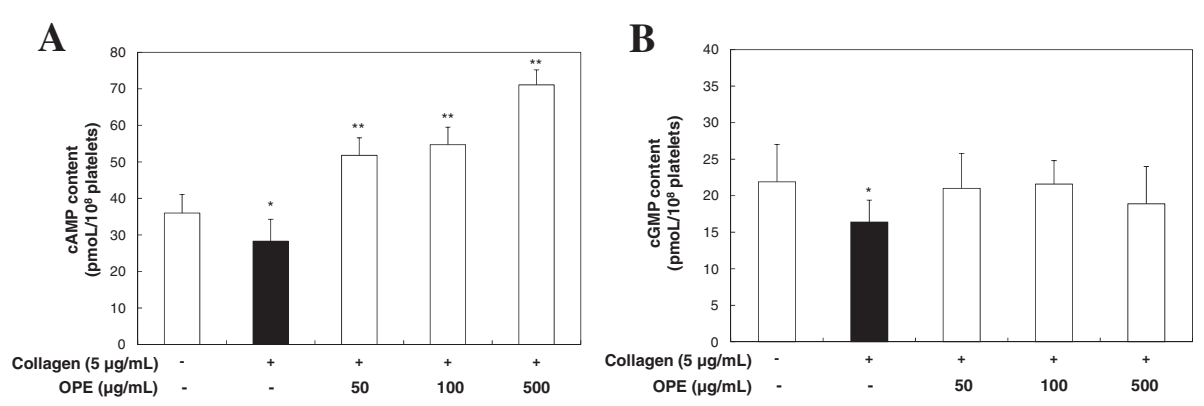

Figure 4 Effects of OPE on CAMP and cGMP production in resting and collagen-stimulated platelets. (A) Effects of OPE On CAMP production in resting and collagen-stimulated platelets. (B) Effects of OPE on CGMP production in resting and collagen-stimulated platelets. Data are expressed as mean $\pm S D(n=3) .{ }^{*} p<0.05$ compared with that of resting platelets. ${ }^{*} p<0.05$ compared with that of collagen-stimulated platelets.

with the activity of PKA, and additional research in this area is recommended.

\section{OPE does not exert toxicity on platelets}

To determine whether OPE has potential toxicity, LDH release assay was examined. Washed platelets $\left(10^{8}\right.$ cells $\left./ \mathrm{mL}\right)$ were incubated with various concentrations of OPE (50, 100 and $500 \mu \mathrm{g} / \mathrm{mL}$ ) for $5 \mathrm{~min}$ as the same method of platelet aggregation reaction. Signs of toxicity were not observed significantly when platelets with OPE (50, 100 and $500 \mu \mathrm{g} / \mathrm{mL})$ were compared to that of control (Figure 5). Therefore, the anti-platelet effects of OPE used in this study did not be affected by its toxic effect.

\section{Conclusion}

We suggest that the inhibitory effects of OPE on collagen-induced platelet aggregation might involve the following pathway; OPE inhibits collagen-stimulated platelet aggregation without any toxicity in vitro, and has anti-platelet effects via up-regulation of cAMP levels but not cGMP and down-regulation of $\mathrm{TXA}_{2}$ through reducing the $\left[\mathrm{Ca}^{2+}\right]_{\mathrm{i}}, \mathrm{COX}-1$ and TXAS activities. Therefore, OPE could be a promising strategy in many cardiovascular diseases such as atherosclerosis, myocardial infarction, and thrombosis.

\section{Methods}

\section{Materials}

Collagen was obtained from Chrono-Log Corp. (Havertown, PA) and LDH cytotoxicity assay, COX-1 fluorescent assay, and $\mathrm{TXB}_{2}$ EIA kits were bought from Cayman Chemical (Ann Arbor, MI). Fura 2-AM, ozagrel, acetylsalicylic acid (ASA), DMSO and quercetin were obtained from Sigma Chemical Corp. (St. Louis, MO). cAMP- and cGMP-EIA kits were purchased from BioVision, Inc. (Milpitas, CA). All other chemicals and reagents used in this study were obtained from Sigma Chemical Corp. (St. Louis, MO).

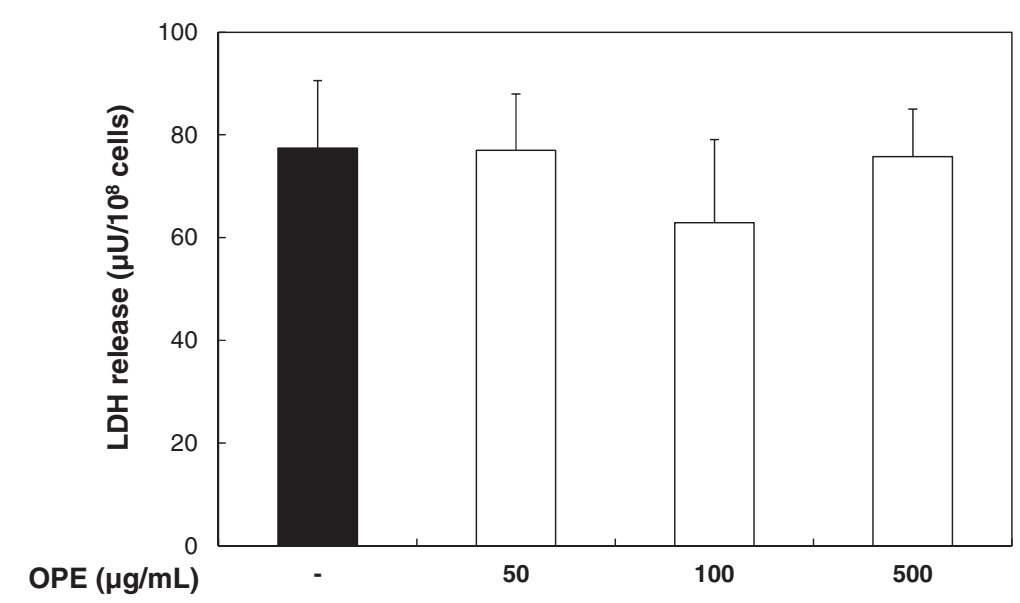

Figure 5 Effect of OPE on the LDH release in washed platelets. Data are expressed as mean $\pm S D(n=3)$. 


\section{Preparation of onion peel extract (OPE)}

Onions were purchased from a local store in South Korea. $3 \mathrm{~g}$ of onion peels were washed in tap water twice and dried. Chopped onion peels were extracted with $60 \mathrm{~mL}$ of $70 \%$ ethanol at $100^{\circ} \mathrm{C}$ for $5 \mathrm{hr}$, and blended by vortex mixer for $10 \mathrm{~min}$. OPE was centrifuged at $1,800 \times \mathrm{g}$ for $10 \mathrm{~min}$ and the clear supernatant was collected. The sediment was blended by vortex mixer for $10 \mathrm{~min}$ after adding $10 \mathrm{~mL}$ of D.W. The mixture was centrifuged at $1,800 \times \mathrm{g}$ for $10 \mathrm{~min}$ and the clear supernatant was collected. The above procedures were repeated for 5 times. Collected OPE was freeze-dried with a freeze dryer model (Ilshin BioBase Co., Ltd., Gyeonggi-do, South Korea) and re-suspended with D.W. to desired concentrations.

\section{Analysis of quercetin in OPE with HPLC}

OPE dissolved in 50\% methanol, and then it was analyzed by HPLC. An Agilent 1100 liquid chromatography system (Agilent Technologies, Santa Clara, CA), equipped with vacuum degasser, quaternary gradient pump, autosampler and diode array detector (DAD) connected to an Agilent ChemStation software. A Zorbax octadecylsilane (ODS) C18 column ( $250 \mathrm{~mm} \times 4.6 \mathrm{~mm}$ id, $5 \mu \mathrm{m})$ and a Zorbax ODS C18 guard column $(12.5 \mathrm{~mm} \times 4.6 \mathrm{~mm}$ id, $5 \mu \mathrm{m})$ were used at a column temperature of $25^{\circ} \mathrm{C}$. The mobile phase consisted of water with $0.1 \%$ acetic acid (A) and acetonitrile $(\mathrm{ACN})(\mathrm{B})$ using the following program: 0-30 min, 0-50\% B; 30-40 min, 50-100\% B. The flow rate was at $1.0 \mathrm{~mL} / \mathrm{min}$ and sample injection volume was $10 \mu \mathrm{L}$. The UV detection was operated at $254 \mathrm{~nm}$. Three concentrations of standard quercetin were injected in duplicate, and then the calibration curve was constructed by plotting the peak area against the concentration of analyte.

\section{Preparation of washed rat platelets}

Rats (8 week-old, male, Sprague-Dawley, specific pathogenfree) were purchased from Taconic Farm., Inc. (Hudson, NY). Rats were housed with a 12 hr light-dark cycle, and fed a normal diet. Tap water was freely available. The rats were sacrificed after starvation for $12 \mathrm{hr}$. They were anesthetized with ethyl ether, and blood was collected from the abdominal vein with $3.2 \%$ sodium citrate $(1: 9, \mathrm{v} / \mathrm{v})$. Plateletrich plasma $(\mathrm{PRP})$ was centrifuged at $125 \times \mathrm{g}$ for $10 \mathrm{~min}$ to remove the red blood cells and PRP was separated with platelet-poor plasma (PPP) and platelet layer. Platelets were washed twice with washing buffer $(138 \mathrm{mM} \mathrm{NaCl}, 2.7 \mathrm{mM}$ $\mathrm{KCl}, 12 \mathrm{mM} \mathrm{NaHCO} 3,0.36 \mathrm{mM} \mathrm{NaH} \mathrm{PO}_{4}, 5.5 \mathrm{mM}$ glucose, and $1 \mathrm{mM}$ EDTA, pH 6.9). The washed platelets were resuspended in suspension buffer $(138 \mathrm{mM}$ $\mathrm{NaCl}, 2.7 \mathrm{mM} \mathrm{KCl}, 12 \mathrm{mM} \mathrm{NaHCO} 3,0.36 \mathrm{mM} \mathrm{NaH}_{2} \mathrm{PO}_{4}$, $0.49 \mathrm{mM} \mathrm{MgCl}_{2}, 5.5 \mathrm{mM}$ glucose, $\mathrm{pH}$ 7.4) to a final concentration of $5 \times 10^{8}$ platelets $/ \mathrm{mL}$. All of the above procedures were carried out at $25^{\circ} \mathrm{C}$ to avoid platelet aggregation on cooling. All animal experiments were carried out according to the guidelines of Konyang University (Daejeon, South Korea) and Ethics Committee.

\section{Measurement of platelet aggregation}

Washed platelets $\left(10^{8}\right.$ cells $\left./ \mathrm{mL}\right)$ were pre-incubated for $3 \mathrm{~min}$ at $37^{\circ} \mathrm{C}$ in the presence of $2 \mathrm{mM}$ exogenous $\mathrm{CaCl}_{2}$ with or without $\mathrm{OPE}(50,100$ and $500 \mu \mathrm{g} / \mathrm{mL})$. After the incubation, washed platelets stimulated with collagen $(5 \mu \mathrm{g} / \mathrm{mL})$ for $5 \mathrm{~min}$. Aggregation was monitored using a Chrono-Log aggregometer at a constant stirring speed of 1,200 rpm (Breddin 2005; Born and Carlo 2006; Maione et al. 2011, 2014). Each aggregation rate was evaluated as an increase in light transmission. The suspension buffer was used as the reference. Quercetin was dissolved in $0.5 \%$ of DMSO, and the effect of DMSO was subtracted from the results.

\section{Determination of $\left[\mathrm{Ca}^{2+}\right]_{i}$}

PRP was incubated with $5 \mu \mathrm{M}$ Fura $2-\mathrm{AM}$ at $37^{\circ} \mathrm{C}$ for 60 min. Because Fura 2-AM is light-sensitive, the tube containing the PRP was covered with aluminum foil during loading. Fura 2-loaded washed platelets $\left(10^{8}\right.$ cells $\left./ \mathrm{mL}\right)$ were pre-incubated for $3 \mathrm{~min}$ at $37^{\circ} \mathrm{C}$ with various concentrations of OPE $(50,100$ and $500 \mu \mathrm{g} / \mathrm{mL})$ in the presence of $2 \mathrm{mM} \mathrm{CaCl}_{2}$ and then stimulated with collagen $(10 \mu \mathrm{g} / \mathrm{mL})$ for $5 \mathrm{~min}$ for evaluation of $\left[\mathrm{Ca}^{2+}\right]_{\mathrm{i}}$. Fura 2 fluorescence was measured with a RF-5301 spectrofluorometer (Shimadzu Corp., Kyoto, Japan) with an excitation wavelength that changed every $0.5 \mathrm{sec}$ from 340 to $380 \mathrm{~nm}$; the emission wavelength was set at $510 \mathrm{~nm}$. The $\left[\mathrm{Ca}^{2+}\right]_{\mathrm{i}}$ values were calculated using the method of Schaeffer (Schaeffer and Blaustein 1989).

\section{Measurement of $\mathrm{TXB}_{2}$}

Washed platelets $\left(10^{8}\right.$ cells $\left./ \mathrm{mL}\right)$ were pre-incubated with or without $\mathrm{OPE}(50,100$ and $500 \mu \mathrm{g} / \mathrm{mL}$ ) for $3 \mathrm{~min}$ in the presence of $2 \mathrm{mM} \mathrm{CaCl}_{2}$, and activated for $5 \mathrm{~min}$ with collagen $(5 \mu \mathrm{g} / \mathrm{mL})$ for $37^{\circ} \mathrm{C}$. The reactions were terminated by the addition of ice-cold EDTA (5 mM) and indomethacin $(0.2 \mathrm{mM})$. The amount of $\mathrm{TXB}_{2}$, a stable metabolite of $\mathrm{TXA}_{2}$, was determined using a $\mathrm{TXB}_{2}$ EIA kit according to the manufacturer's recommendations. Quercetin was dissolved in $0.5 \%$ of DMSO, and the effect of DMSO was subtracted from the results.

\section{TXAS activity assay}

Platelets in a suspension buffer containing $1 \%$ protease inhibitor were sonicated. The platelet lysates $(10 \mu$ g-protein $)$ were pre-incubated with or without OPE (50, 100 and 500 $\mu \mathrm{g} / \mathrm{mL}$ ) at $37^{\circ} \mathrm{C}$ for $5 \mathrm{~min}$. The reactions were initiated by the addition of $\mathrm{PGH}_{2}$. After incubation for $1 \mathrm{~min}$ at $37^{\circ} \mathrm{C}$, the reaction was terminated by the addition of $1 \mathrm{M}$ citric acid and neutralization with $1 \mathrm{~N} \mathrm{NaOH}$. Ozagrel (11 nM) 
was used as a positive control of TXAS inhibitor. The amount of $\mathrm{TXB}_{2}$, a stable metabolite of $\mathrm{TXA}_{2}$, was determined using a $\mathrm{TXB}_{2}$ EIA kit according to the manufacturer's recommendations.

\section{COX-1 activity assay}

Platelets in a suspension buffer containing $1 \%$ protease inhibitor were sonicated. The platelet lysates $(10 \mu \mathrm{g}$-protein $)$ were incubated with or without various concentrations of OPE (50, 100 and $500 \mu \mathrm{g} / \mathrm{mL}$ ) for $30 \mathrm{~min}$ at $37^{\circ} \mathrm{C}$. The reactions were initiated by the addition of arachidonic acid. After incubation for $1 \mathrm{~min}$ at $37^{\circ} \mathrm{C}, \mathrm{COX}-1$ activity was assayed with COX-1 activity fluorescent assay kit according to the manufacturer's recommendations. SC-560 (330 $\mathrm{nM})$ and ASA $(500 \mu \mathrm{M})$ were used as a positive control of COX-1 inhibitor. COX-1 activity was measured with Synergy HT multi-model microplate reader (BioTek Instruments, Winooski, VT).

\section{Measurement of CAMP and cGMP}

Washed platelets $\left(10^{8}\right.$ cells $\left./ \mathrm{mL}\right)$ were pre-incubated for $3 \mathrm{~min}$ at $37^{\circ} \mathrm{C}$ with various concentrations of OPE (50, 100 and $500 \mu \mathrm{g} / \mathrm{mL}$ ) in the presence of $2 \mathrm{mM} \mathrm{CaCl}_{2}$, and then stimulated with collagen $(5 \mu \mathrm{g} / \mathrm{mL})$ for $5 \mathrm{~min}$ for platelet aggregation. The aggregation was terminated by the addition of $80 \%$ ice-cold ethanol. cAMP and cGMP were measured using cAMP and cGMP EIA kits according to the manufacturer's recommendations.

\section{LDH assay}

To assess whether OPE has toxicity, we examined the effect of OPE on LDH release in vitro, which is a stable enzyme normally found in the cytosol of cells, but rapidly releases into the supernatant upon damage of cell membrane. Washed platelets $\left(10^{8}\right.$ platelets $\left./ \mathrm{mL}\right)$ were incubated for $5 \mathrm{~min}$ at $37^{\circ} \mathrm{C}$ with various concentrations of OPE (50, 100 and $500 \mu \mathrm{g} / \mathrm{mL})$, and then the supernatant was measured by an LDH assay kit according to the manufacturer's recommendations.

\section{Statistical analysis}

The experiment results are expressed as the mean \pm SD Statistical analysis was performed by two tailed unpaired Student's t-test or ANOVA as appropriate. If this analysis indicated significant differences among the group means, each group was compared by the Scheffe's method for post hoc tests (Brown 2005).

\section{Competing interests}

The authors declare that they have no competing interests.

\section{Authors' contributions}

J-Y Ro and J-H Ryu designed the study: collected data, interpreted the results and drafted the manuscript. $\mathrm{H}$-J Park advised in interpreting nonsignificant results. All authors read and approved the final manuscript.

\section{Acknowledgments}

This work was supported by the Korea Foundation for the Advancement of Science \& Creativity (KOFAC) funded by the Korean Government (MOE) (20140021C910101S000100) and Basic Science Research Program through the National Research Foundation of Korea (NRF) funded by the Ministry of Education, Science and Technology (2010-0024028).

\section{Author details}

${ }^{1}$ Department of Biomedical Laboratory Science, College of Medical Science, Konyang University, 685, Gasuwon-dong, Seo-gu, Daejeon 302-718, Korea. ${ }^{2}$ Department of Biomedical Laboratory Science, College of Biomedical Science and Engineering and Regional Research Center, Inje University, 607, Obang-dong, Gimhae, Gyungnam 621-749, Korea. ${ }^{3}$ Present address:

Department of Microbiology and Immunology, Institute of Medical Science, Tokyo University, Minato-ku, Tokyo 108-8639, Japan.

Received: 12 September 2014 Accepted: 2 January 2015

Published online: 13 January 2015

\section{References}

Ali M, Bordia T, Mustafa T (1999) Effect of raw versus boiled aqueous extract of garlic and onion on platelet aggregation. Prostaglandins Leukot Essent Fatty Acids 60:43-47

Aszodi A, Pfeifer A, Ahmad M, Glauner M, Zhou XH, Ny L et al (1999) The vasodilatorstimulated phosphoprotein (VASP) is involved in CGMP- and CAMP-mediated inhibition of agonist-induced platelet aggregation, but is dispensable for smooth muscle function. EMBO J 18:37-48

Baumgartner HR, Haudenschild C (1972) Adhesion of platelets to subendothelium. Ann N Y Acad Sci 201:22-36

Bhatt DL, Topol EJ (2003) Scientific and therapeutic advances in antiplatelet therapy. Nat Rev Drug Discov 2:15-28

Bordia A, Bansal HC, Arora SK, Singh SV (1975) Effect of the essential oils of garlic and onion on alimentary hyperlipemia. Atherosclerosis 21:15-19

Bordia T, Mohammed N, Thomson M, Ali M (1996) An evaluation of garlic and onion as antithrombotic agents. Prostaglandins Leukot Essent Fatty Acids 54:183-186

Born G, Carlo P (2006) Antiplatelet drugs. Br J Pharmacol 147(S1):S241-S251

Brass LF, Joseph SK (1985) A role for inositol triphosphate in intracellular $\mathrm{Ca}^{2+}$ mobilization and granule secretion in platelets. J Biol Chem 260:15172-15179

Breddin HK (2005) Can platelet aggregometry be standardized? Platelets 16(3-4):151-158

Briggs WH, Folts JD, Osman HE, Goldman IL (2001) Administration of raw onion inhibits platelet-mediated thrombosis in dogs. J Nutr 131:2619-2622

Brown AM (2005) A new software for carrying out one-way ANOVA post hoc tests. Comput Methods Programs Biomed 79:89-95

Bunting S, Moncada S, Vane JR (1983) The prostacyclin-thromboxane $A_{2}$ balance: pathophysiological and therapeutic implications. Br Med Bull 39:271-276

Cho MJ, Liu J, Pestina TI, Steward SA, Thomas DW, Coffman TM et al (2003) The roles of alpha Illb beta 3-mediated outside-in signal transduction, thromboxane $A_{2}$ and adenosine diphosphate in collagen-induced platelet aggregation. Blood 101:2646-2651

Cho HJ, Cho JY, Rhee MH, Lim CR, Park HJ (2006) Cordycepin (3'-deoxyadenosine) inhibits human platelet aggregation induced by U46619, a TXA 2 analogue. J Pharm Pharmacol 58:1677-1682

Crozier A, Lean ME, McDonald MS, Black C (1997) Quantitative analysis of the flavonoid content of commercial tomatoes, onions, lettuce, and celery. J Agric Food Chem 45:590-595

Davi G, Patrono C (2007) Platelet activation and atherothrombosis. N Engl J Med 357:2482-2494

Detwiler TC, Charo I, Feinman R (1978) Evidence that calcium regulates platelet function. Thromb Haemost 40:207-211

Ewald C, Fjelkner-Modig S, Johansson K, Sjöholm I, Åkesson B (1999) Effect of processing on major flavonoids in processed onions, green beans, and peas. Food Chem 64:231-235

FitzGerald GA, Healy C, Daugherty J (1987) Thromboxane A2 biosynthesis in human disease. Fed Proc 46:154-158

Glässer G, Graefe E, Struck F, Veit M, Gebhardt R (2002) Comparison of antioxidative capacities and inhibitory effects on cholesterol biosynthesis of quercetin and potential metabolites. Phytomedicine 9:33-40

Gresele P, Deckmyn H, Nenci GG, Vermylen J (1991) Thromboxane synthase inhibitors, thromboxane receptor antagonists and dual blockers in thrombotic disorders. Trends Pharmacol Sci 12:158-163 
Halbrugge M, Friedrich C, Eigenthaler M, Schanzenbacher P, Walter U (1990) Stoichiometric and reversible phosphorylation of a $46-\mathrm{kDa}$ protein in human platelets in response to CGMP- and CAMP-elevating vasodilators. J Biol Chem 265:3088-3093

Hamberg M, Svensson J, Samuelsson B (1975) Thromboxanes: a new group of biologically active compounds derived from prostaglandin endoperoxides. Proc Natl Acad Sci U S A 72:2994-2998

Hertog MG, Hollman PC, Katan MB (1992) Content of potentially anticarcinogenic flavonoids of 28 vegetables and 9 fruits commonly consumed in the Netherlands. J Agric Food Chem 40:2379-2383

Houston DS, Shepherd JT, Vanhoutte PM (1986) Aggregating human platelets cause direct contraction and endothelium-dependent relaxation of isolated canine coronary arteries. Role of serotonin, thromboxane $A_{2}$, and adenine nucleotides. J Clin Invest 78:539

Hubbard GP, Stevens JM, Cicmil M, Sage T, Jordan PA, Williams CM et al (2003) Quercetin inhibits collagen-stimulated platelet activation through inhibition of multiple components of the glycoprotein VI signaling pathway. J Thromb Haemost 1:1079-1088

Hubbard GP, Wolffram S, de Vos R, Bovy A, Gibbins JM, Lovegrove JA (2006) Ingestion of onion soup high in quercetin inhibits platelet aggregation and essential components of the collagen-stimulated platelet activation pathway in man: a pilot study. Br J Nutr 96:482-488

Jackson SP, Schoenwaelder SM (2003) Antiplatelet therapy: in search of the 'magic bullet'. Nat Rev Drug Discov 2:775-789

Jang EK, Azzam JE, Dickinson NT, Davidson MM, Haslam RJ (2002) Roles for both cyclic GMP and cyclic AMP in the inhibition of collagen-induced platelet aggregation by nitroprusside*. Brit J Haematol 117:664-675

Kapoor JR (2008) Platelet activation and atherothrombosis. N Engl J Med 358:1638, author reply 1638-1639

Kawakishi S, Morimitsu Y (1988) New inhibitor of platelet aggregation in onion oil. Lancet 2:330

Kawamoto E, Sakai Y, Okamura Y, Yamamoto Y (2004) Effects of boiling on the antihypertensive and antioxidant activities of onion. J Nutr Sci Vitaminol (Tokyo) 50:171-176

Kris-Etherton P, Lefevre M, Beecher G, Gross M, Keen C, Etherton T (2004) Bioactive compounds in nutrition and health-research methodologies for establishing biological function: the antioxidant and anti-inflammatory effects of flavonoids on atherosclerosis. Annu Rev Nutr 24:511-538

Li Z, Ajdic J, Eigenthaler M, Du X (2003) A predominant role for cAMP-dependent protein kinase in the CGMP-induced phosphorylation of vasodilator-stimulated phosphoprotein and platelet inhibition in humans. Blood 101:4423-4429

Maione F, Cicala C, Liverani E, Mascolo N, Perretti M, D'Acquisto F (2011) IL-17A increases ADP-induced platelet aggregation. Biochem Biophys Res Commun 408(4):658-662

Maione F, De Feo V, Caiazzo E, De Martino L, Cicala C, Mascolo N (2014) Tanshinone IIA, a major component of Salvia milthorriza Bunge, inhibits platelet activation via Erk-2 signaling pathway. J Ethnopharmacol 155(2):1236-1242

Miller OV, Johnson RA, Gorman RR (1977) Inhibition of PGE1-stimulated CAMP accumulation in human platelets by thromboxane $A_{2}$. Prostaglandins 13:599-609

Moon C, Jung Y, Kim M, Lee S, Baik E, Park S (2000) Mechanism for antiplatelet effect of onion: AA release inhibition, thromboxane $A_{2}$ synthase inhibition and $\mathrm{TXA}_{2} / \mathrm{PGH}_{2}$ receptor blockade. Prostaglandins Leukot Essent Fatty Acids 62:277-283

Müller B (1990) Pharmacology of thromboxane $A_{2}$, prostacyclin and other eicosanoids in the cardiovascular system. Therapie 46:217-221

Nieswandt B, Watson SP (2003) Platelet-collagen interaction: is GPVI the central receptor? Blood 102:449-461

Nishikawa M, Tanaka T, Hidaka H (1980) Ca ${ }^{2+}$-calmodulin-dependent phosphorylation and platelet secretion. Nature 287:863-865

Offermanns S (2006) Activation of platelet function through G protein-coupled receptors. Circ Res 99:1293-1304

Prakash D, Suri S, Upadhyay G, Singh BN (2007) Total phenol, antioxidant and free radical scavenging activities of some medicinal plants. Int J Food Sci Nutr 58:18-28

Schaeffer J, Blaustein M (1989) Platelet free calcium concentrations measured with fura-2 are influenced by the transmembrane sodium gradient. Cell Calcium 10:101-113

Trovati M, Anfossi G, Massucco P, Mattiello L, Costamagna C, Piretto V et al (1997) Insulin stimulates nitric oxide synthesis in human platelets and, through nitric oxide, increases platelet concentrations of both guanosine-3', 5'-cyclic monophosphate and adenosine-3', 5'-cyclic monophosphate. Diabetes 46:742-749

Vilahur G, Casani L, Badimon L (2007) A thromboxane $\mathrm{A}_{2}$ /prostaglandin $\mathrm{H}_{2}$ receptor antagonist ( $\$ 18886$ ) shows high antithrombotic efficacy in an experimental model of stent-induced thrombosis. Thromb Haemost 98:662-669

Williamson JR, Cooper RH, Joseph SK, Thomas AP (1985) Inositol trisphosphate and diacylglycerol as intracellular second messengers in liver. Am J Physiol 248:C203-C216

\section{Submit your manuscript to a SpringerOpen ${ }^{\circ}$ journal and benefit from:}

- Convenient online submission

- Rigorous peer review

- Immediate publication on acceptance

- Open access: articles freely available online

- High visibility within the field

- Retaining the copyright to your article

Submit your next manuscript at $>$ springeropen.com 